\title{
Evaluation of The Predictability of Platelet Mass Index for Short-Term Mortality in Patients with COVID-19: A Retrospective Cohort Study
}

\section{COVID-19 Hastalarında Kısa Süreli Mortalite İçin Trombosit Kitle İndeksinin Öngörülebilirliğinin Değerlendirilmesi: Retrospektif Bir Grup Çalışması}

\author{
Abdullah Algın', @Serdar Özdemir ${ }^{1}$ \\ 'Department of Emergency Medicine, University of Health Sciences Ümraniye Training and Research Hospital, İstanbul, Turkey
}

\begin{abstract}
Objective: This study aimed to determine the predictability of platelet mass index (PMI) for short-term mortality in patients with COVID-19.

Material and Method: This retrospective, observational, cohort study included corrected COVID-19 patients. Demographics, clinical characteristics, biochemical and hematological parameters and the data of all-cause mortality within 30 days after admission were noted. The receiver operating characteristic curve analysis and odds ratio were performed to determine the discriminative ability of the scores.

Results: Of the 1564 patients, with mean of age of $44 \pm 16$ years included in the study. A total of 57 (3.6\%) patients died within 30 days of emergency department presentation. There was a statistically significant difference between the survivor and nonsurvivor groups in terms of the platelet count, mean platelet volume (MPV) and PMI. According to the best Youden's index, the cut-off value for the platelet count was determined as 146 (sensitivity: 91.8\%, specificity: $87.2 \%$ ), and the area under curve (AUC) value was 0.593 (95\% confidence interval 56.7-61.9). According to the best Youden's index, the cut-off value for the MPV was determined as 11 (sensitivity: $24.6 \%$, specificity: $91 \%$ ), and the AUC value was 0.579 (95\% confidence interval 55.2-60.5). According to the best Youden's index, the cut-off value for the PMI was determined as 1513 (sensitivity: $28.1 \%$, specificity: $87.2 \%$ ), and the AUC value was 0.555 (95\% confidence interval 52.8-58.2).
\end{abstract}

Conclusion: Platelet count, MPV and PMI were not predictor of 30day mortality in patients with confirmed COVID-19 in emergency department.

Keywords: COVID-19, SARS-Cov-2, blood tests, coronavirus, platelet, laboratory
Öz

Amaç: Çalışmamızda, COVID-19 hastalarında trombosit kitle indeksinin (PMI) kısa dönem mortalite için öngörülebilirliğini belirlemeyi amaçladık.

Gereç ve Yöntem: Retrospektif, gözlemsel kohort çalışmamıza, doğrulanmış COVID-19 hastaları dahil edildi. Demografik, klinik özellikler, biyokimyasal ve hematolojik parametreler ve başvurudan sonraki 30 gün içinde tüm nedenlere bağlı ölüm verileri kaydedildi. Parametrelerin öngörebilirliklerini tespit edebilmek için alıcı işletim karakteristik eğrisi analizi ve olasılık oranı yapıldı.

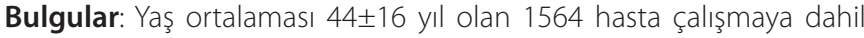
edildi. Acil servise başvurduktan sonraki 30 gün içinde toplam 57 $(\% 3,6)$ hasta öldü. Trombosit sayısı, ortalama trombosit hacmi (MPV) ve PMI açısından yaşayan ve yaşamayan gruplar arasında istatistiksel olarak anlamlı bir fark vardı. En iyi Youden indeksine göre trombosit sayısı için cut-off değeri 146 (duyarlılık: \%91,8, özgüllük: \%87,2) ve eğri altındaki alan (EAA) değeri 0,593 (\%95 güven aralığı 56,7-\%) olarak belirlendi. 61,9). En iyi Youden indeksine göre MPV için cut-off değeri 11 (duyarlıık: \%24,6, özgüllük: \%91) ve EAA değeri 0,579 (\%95 güven aralığı 55,2-60,5) olarak belirlendi. En iyi Youden indeksine göre PMI için kesme değeri 1513 (duyarlılı: \%28,1, özgüllük: \%87,2) ve EAA değeri 0,555 (\%95 güven aralığı 52,8-58,2) olarak belirlendi.

Sonuç: Acil serviste doğrulanmış COVID-19 olan hastalarda trombosit sayısı, MPV ve PMI 30 günlük mortalitenin öngörücüsü değildir.

Anahtar Kelimeler: COVID-19, SARS-CoV-2, kan testleri, korona virüs, trombosit, laboratuvar

Corresponding (İletişim): Serdar Özdemir, Department of Emergency Medicine, University of Health Sciences Ümraniye Training and Research Hospital, İstanbul, Turkey

E-mail (E-posta): dr.serdar55@hotmail.com

Received (Geliş Tarihi): 22.07.2021 Accepted (Kabul Tarihi): 24.08.2021 


\section{INTRODUCTION}

The coronavirus, a respiratory RNA virus, caused an epidemic in Wuhan, China at the end of 2019, causing severe acute respiratory failure. For this reason, this epidemic, which forces the social lives, economies, and health systems of countries, was called COVID-19. ${ }^{[1]}$ From March 2020, when it was declared a pandemic, to June 2021, it infected more than 180 million people and caused the deaths of more than 3.5 million people.

With the spread of the disease around the world, many researchers studied the course of the disease and prognostic factors to use resources effectively. ${ }^{[2-4]}$ It has been shown that an increase in inflammatory markers such as C-reactive protein (CRP), interleukin 6, leukocyte count, and erythrocyte sedimentation rate can be a marker of critical illness and mortality. ${ }^{[2,3,5]}$ On the other hand, it has been shown that the decrease in markers such as lymphocyte count and albumin can also be used in the detection of critical patients and predicting mortality. Researchers constantly tried to find better markers. ${ }^{[4,5]}$ In order to achieve better predictability, hematological ratios such as neutrophil-to-lymphocyte ratio (NLR), lymphocyte-to-CRP ratio, lymphocyte-to-monocyte ratio and platelet-to-lymphocyte ratio (PLR) were studied. [4-6] The predictability of mortality and critical illness of platelet count and platelet-related parameters was studied on COVID-19 patients. It has been reported that platelet count and mean platelet volume (MPV) may be a predictor of mortality for COVID-19. Thus, we hypothesized that the platelet mass index (PMI), which is formed by multiplying platelet count and MPV, may be a predictor in COVID-19. To the best of our knowledge, there is no research in the literature evaluating the predictability of PMI for short-term mortality in patients with COVID-19. In this study, we aimed to determine the predictability of PMI for short-term mortality in patients with COVID-19 in emergency department (ED).

\section{MATERIALS AND METHOD}

\section{Study Design}

This retrospective cohort study was conducted at University of Health Sciences, Ümraniye Training and Research Hospital a 695-bed tertiary education hospital with 1110 patient admissions per day (annual average) to ED. Data of the patients who admitted our pandemic clinics between June 15, 2021 and July 15, 2021 collected retrospectively.

\section{Study Population}

Our study population was patients who admitted to pandemic clinic for COVID-19 between June 15, 2021 and July 15, 2021. All patients with a positive test result for SARS-CoV-2, who were tested for platelet count and MPV, were included in the study. Hospitalization and intensive care admission decision of the patients was made by the emergency medicine specialist. The follow-up of hospitalized patients was done by a pulmonologist or an infectious disease specialist or an internist. Hospitalization decisions and treatment planning were made in accordance with the COVID-19 Outbreak Management and Working Guideline of Ministry of Health.

\section{Data Collection}

Demographics, clinical characteristics (included comorbidities, and symptoms), vital parameters on admission laboratory findings, and emergency department outcomes of each patient were obtained from the hospital computer-based patient data system and analyzed by researchers. Emergency department outcomes were noted as discharged, hospitalized to inpatient clinics, and admitted to intensive care unit. Comorbidities were recorded as coronary artery disease, diabetes mellitus, chronic obstructive pulmonary diseases, hypertension, congestive heart failure, chronic renal failure, active malignancy, and immunodeficiency. Symptoms of disease were recorded as fever, cough, sputum, dyspnea, weakness, myalgia, smell or taste defects, sore throat, headache, vomiting or nausea, and diarrhea. Systolic blood pressure, diastolic blood pressure, body temperature, pulse pressure, and peripheral oxygen saturation were recorded as vital parameters. The documented laboratory parameters were BUN, creatinine, CRP, albumin, white blood cell count, neutrophil count, lymphocyte count, platelet count, MPV, and mean corpuscular volume. NLR, PLR, and PMI were calculated by researcher.

To confirm COVID-19, ORF1 $\mathrm{ab}$ and N gene of SARS-CoV-2 were embattled and Biorad CFX 96 platform were used. Twentynine and above $\mathrm{Ct}$ values were considered positive. Tests that were positive for both genes of ORFlab and $\mathrm{N}$ were reported as SARS-CoV-2 positive.

\section{Statistical Analysis}

IBM SPSS Statistics for Mac, Version 27.0. Armonk, NY, IBM Corp was used to perform statistical analyses. To assess the conformance of variables to normal distribution the Kolmogorov-Smirnov test was conducted. The data that matched normal distribution were presented with mean and standard deviation and values, and the remaining data were expressed as interquartile range and median values. Categorical data were presented with percentages and the number of cases. For the comparison of qualitative and quantitative data between two groups, the Mann-Whitney $U$ and chi-square tests were used. The Bonferroni correction was used a method to counteract the problem of multiple comparisons of laboratory parameters. We also formed a receiver-operating characteristic curve (ROC) for short-term mortality and obtained the area under the curve (AUC) for individual variables by using MedCalc software (MedCalc Software Ltd, Ostend, Belgium). A p value lower than 0.05 was statistically significant in all analyses.

\section{Ethics}

The ethical committee approval of our study was obtained from the Ethical Committee of University of Health Sciences, Ümraniye Training and Research Hospital (approval number: B.10. 1.TKH.4.34 .H.GP.0.01/235). We retrospectively reviewed 
the secondary data recorded from the computer-based patient data system of hospital. However, the recorded data didn't include any personal identifiable data; it included clinical information solely. Therefore, the necessity for informed consent was wild.

\section{RESULTS}

\section{Patient Characteristics}

Of the 1564 patients included in the study, 801(53.2\%) were male. The mean of age of the 1564 patients was $44 \pm 16$ years. A total of 57 patients died within 30 days of ED presentation. The rate of 30 -day mortality was $3.6 \%$ for the study cohort. The demographic characteristics, clinical outcomes for the first 24 hours, comorbid diseases, symptoms, vital parameters at presentation, and mortality data comparison of them between the survivor and non-survivor groups are shown in Table 1. Initial laboratory findings comparison of them between the survivor and non-survivor groups are presented in Table 2. Nine hundred ninety-one of all patients were discharged, 550 were hospitalized to inpatient clinics, 23 were admitted to intensive care unit. Nine hundred eighty-nine of the patients who survived were discharged, 516 of them were hospitalized to inpatient clinics, and two of them were admitted to intensive care unit. Thirty-four of the patients who non-survived were hospitalized to inpatient clinics, 21 of them were admitted to intensive care unit. There was a statistically significant difference between the survivor and non-survivor groups in terms of the ED outcomes $(p<0.001$, Mann-Whitney U test).

\section{Laboratory Values and Outcomes}

Significant differences were observed between the survivor and non-survivor groups in laboratory parameters: Blood urea nitrogen [25.68 (21.4- 32.1) versus $47.08(34.24-70.62) \mathrm{mg} /$ $\mathrm{dL}, \mathrm{p}=<0.001]$, creatinine [0.83 (0.73-0.98) versus $1.2(0.92-$ 1.53) $\mathrm{mg} / \mathrm{dL}, \mathrm{p}=<0.001$ ], albumin [ $42.6 \pm 4.1$ versus $36.1 \pm 5.2$ $\mathrm{mg} / \mathrm{dL}, \mathrm{p}=<0.001], \mathrm{CRP}$ [2 (1-5) versus 11.5 (8-16) $\mathrm{mg} / \mathrm{L}, \mathrm{p}=$ 0.003 ], hemoglobin [ $13.8 \pm 1.7$ versus $12.7 \pm 2.2 \mathrm{~g} / \mathrm{dL}, \mathrm{p}=0.001$ ], neutrophil count [3.63 (2.71-4.89) versus 6.25 (4.55-8.75), $\mathrm{p}=<0.001]$, and NLR [ $2.17(1.48-356)$ versus 6.1 (3.59-8.84) $p=<0.001]$.

The analysis of the ROC curve was performed to determine the discriminative ability of the laboratory parameters in 30-day mortality. Table $\mathbf{3}$ and Figure $\mathbf{1}$ present according to the best Youden's index the cut-off values of NLR, PLR, platelet count, MPV, and PMI and their sensitivity, specificity, AUC, positive and negative predictive values, likelihood ratios, accuracy and

\begin{tabular}{|c|c|c|c|c|}
\hline Variables & $\begin{array}{c}\text { Total } \\
n=1564 \\
(\%, \text { Standard deviation) }\end{array}$ & $\begin{array}{c}\text { Survivor } \\
\mathrm{n}=1507(96.4 \%) \\
\text { (\%, Standard deviation) }\end{array}$ & $\begin{array}{c}\text { Non-survivor } \\
n=57(3.6 \%) \\
\text { (\%, Standard deviation) }\end{array}$ & p values \\
\hline Age, years & $44 \pm 16$ & $43 \pm 16$ & $71 \pm 13$ & $<0.001$ \\
\hline Gender & & & & 0.137 \\
\hline Male & 837 (53.5\%) & $801(53.2 \%)$ & $36(63.2 \%)$ & \\
\hline Female & 727 (46.5\%) & $706(46.8 \%)$ & $21(36.8)$ & \\
\hline \multicolumn{5}{|l|}{ Comorbidities } \\
\hline Chronic obstructive pulmonary diseases & $35(2.2 \%)$ & $30(2 \%)$ & $5(8.8 \%)$ & 0.008 \\
\hline Hypertension & $201(12.9 \%)$ & $178(11.8 \%)$ & $23(40.4 \%)$ & $<0.001$ \\
\hline Diabetes mellitus & $153(9.8 \%)$ & $143(9.5 \%)$ & $10(17.5 \%)$ & 0.044 \\
\hline Coronary artery disease & $47(3 \%)$ & $38(2.5 \%)$ & $9(15.8 \%)$ & $<0.001$ \\
\hline Congestive heart failure & $15(1 \%)$ & $9(0.6 \%)$ & $6(10.5 \%)$ & $<0.001$ \\
\hline Chronic renal failure & $8(0.5 \%)$ & $4(0.3 \%)$ & $4(7 \%)$ & $<0.001$ \\
\hline Active malignancy & $16(1 \%)$ & $12(0.8 \%)$ & $4(7 \%)$ & 0.002 \\
\hline Immunodeficiency & $3(0.2)$ & $2(0.1 \%)$ & $1(1.8 \%)$ & 0.105 \\
\hline \multicolumn{5}{|l|}{ Frequency of symptoms } \\
\hline Fever & $522(33.4 \%)$ & $499(33.1 \%)$ & $23(40.4 \%)$ & 0.255 \\
\hline Cough & $889(56.8 \%)$ & $865(57.4 \%)$ & $24(42.1 \%)$ & 0.022 \\
\hline Sputum & $44(2.8 \%)$ & $41(2.7 \%)$ & $3(5.3 \%)$ & 0.214 \\
\hline Shortness of breath & $377(24.1 \%)$ & $351(23.3 \%)$ & $26(45.6 \%)$ & $<0.001$ \\
\hline Weakness & $285(18.2 \%)$ & $280(18.6 \%)$ & $5(8.8 \%)$ & 0.060 \\
\hline Myalgia & $237(15.2 \%)$ & $632(15.4 \%)$ & $5(8.8 \%)$ & 0.171 \\
\hline Smell or taste defects & $111(7.1 \%)$ & $111(7.4 \%)$ & 0 & 0.030 \\
\hline Headache & $130(8.3 \%)$ & $129(8.6 \%)$ & $1(1.8 \%)$ & 0.083 \\
\hline Sore throat & $158(10.1 \%)$ & $154(10.2 \%)$ & $4(7 \%)$ & 0.469 \\
\hline Nausea-vomiting & $64(4.1 \%)$ & $57(3.8 \%)$ & $7(12.3 \%)$ & 0.007 \\
\hline Diarrhea & $74(4.7 \%)$ & $71(4.7 \%)$ & $3(5.3 \%)$ & 0.749 \\
\hline \multicolumn{5}{|l|}{ Vital parameters } \\
\hline Systolic blood pressure & $124 \pm 18$ & $123 \pm 17$ & $138 \pm 26$ & 0.001 \\
\hline Diastolic blood pressure & $73 \pm 10$ & $73 \pm 10$ & $74 \pm 11$ & 0.628 \\
\hline Pulse pressure & $86 \pm 20$ & $85 \pm 19$ & $97 \pm 25$ & 0.009 \\
\hline Body temperature & $38.8 \pm 0.7$ & $38.9 \pm 0.6$ & $37.1 \pm 0.8$ & 0.700 \\
\hline Oxygen saturation & $96 \pm 7$ & $96 \pm 5$ & $87 \pm 11$ & $<0.001$ \\
\hline
\end{tabular}


Table 2. Laboratory parameters of the enrolled patients and comparison of them between the survivor and non-survivor groups

\begin{tabular}{|c|c|c|c|c|}
\hline Variables & $\begin{array}{c}\text { Total } \\
\text { Median/Mean }\left(25^{\text {th }}-75^{\text {th }}\right. \\
\text { percentiles/ Standard deviation })\end{array}$ & $\begin{array}{c}\text { Survivor } \\
\text { Median/Mean }\left(25^{\text {th }}-75^{\text {th }}\right. \\
\text { percentiles/ Standard deviation) }\end{array}$ & $\begin{array}{c}\text { Non-survivor } \\
\text { Median/Mean }\left(25^{\text {th }}-75^{\text {th }}\right. \\
\text { percentiles/ Standard deviation) }\end{array}$ & $p$ values \\
\hline Blood urea nitrogen, $\mathrm{mg} / \mathrm{dL}$ & $27.89(21.40-34.24)$ & $25.68(21.4-32.1)$ & 47.08 (34.24-70.62) & $<0.001$ \\
\hline C-Reactive Protein, mg/L & $2(1-6)$ & $2(1-5)$ & $11.5(8-16)$ & 0.003 \\
\hline Albumin, $\mathrm{mg} / \mathrm{dL}$ & $42.2 \pm 4.5$ & $42.6 \pm 4.1$ & $36.1 \pm 5.2$ & $<0.001$ \\
\hline White blood cell count & $7.8(5.3-8.1)$ & $6.1(5.1-7.8)$ & $23.1(12.8-26.8)$ & 0.100 \\
\hline Lymphocyte count & $1.70 \pm 0.77$ & $1.71 \pm 0.74$ & $1.41 \pm 1.35$ & 0.096 \\
\hline Hemoglobin, g/dL & $13.7 \pm 1.7$ & $13.8 \pm 1.7$ & $12.7 \pm 2.2$ & 0.001 \\
\hline Hematocrit & $40.9 \pm 4.5$ & $41 \pm 4.3$ & $38.4 \pm 6.3$ & 0.004 \\
\hline Platelet count & $219 \pm 60$ & $220 \pm 58$ & $202 \pm 87$ & 0.143 \\
\hline Mean corpuscular volume & $85.4 \pm 5.7$ & $85.4 \pm 5.5$ & $87.1 \pm 7.7$ & 0.100 \\
\hline
\end{tabular}

Table 3. Ability of the investigated laboratory parameters to predict 30-day all-cause mortality following ED admission

\begin{tabular}{lccccccccccc} 
& AUC & Cut-off & Sensitivity & Specificity & PPV & NPV & LR+ & LR- & Accuracy & 95\% Cl & p-value \\
\hline NLR & 0.807 & 3.58 & 75.4 & 75.6 & 11.8 & 98.6 & 3.09 & 0.32 & 51.03 & $78.5-82.8$ & $<0.001$ \\
PLR & 0.642 & $>158.33$ & 57.9 & 67.4 & 7.2 & 97.4 & 1.77 & 0.63 & 25.25 & $61.6-66.8$ & $<0.001$ \\
Platelet & 0.593 & $\leq 146$ & 91.8 & 87.8 & 12.9 & 96.7 & 3.41 & 0.78 & 19.83 & $56.7-61.9$ & 0.035 \\
MPV & 0.579 & $>11$ & 24.6 & 91 & 10.6 & 96.5 & 2.73 & 0.83 & 15.56 & $55.2-60.5$ & 0.057 \\
PMI & 0.555 & $\leq 1513$ & 28.1 & 89.2 & 10.2 & 96.6 & 2.61 & 0.81 & 17.32 & $52.8-58.2$ & 0.219 \\
\hline
\end{tabular}

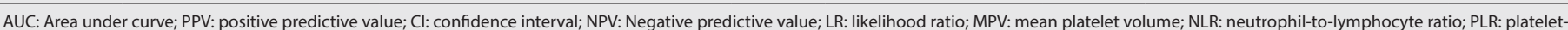
to-lymphocyte ratio; PMI: platelet mass index

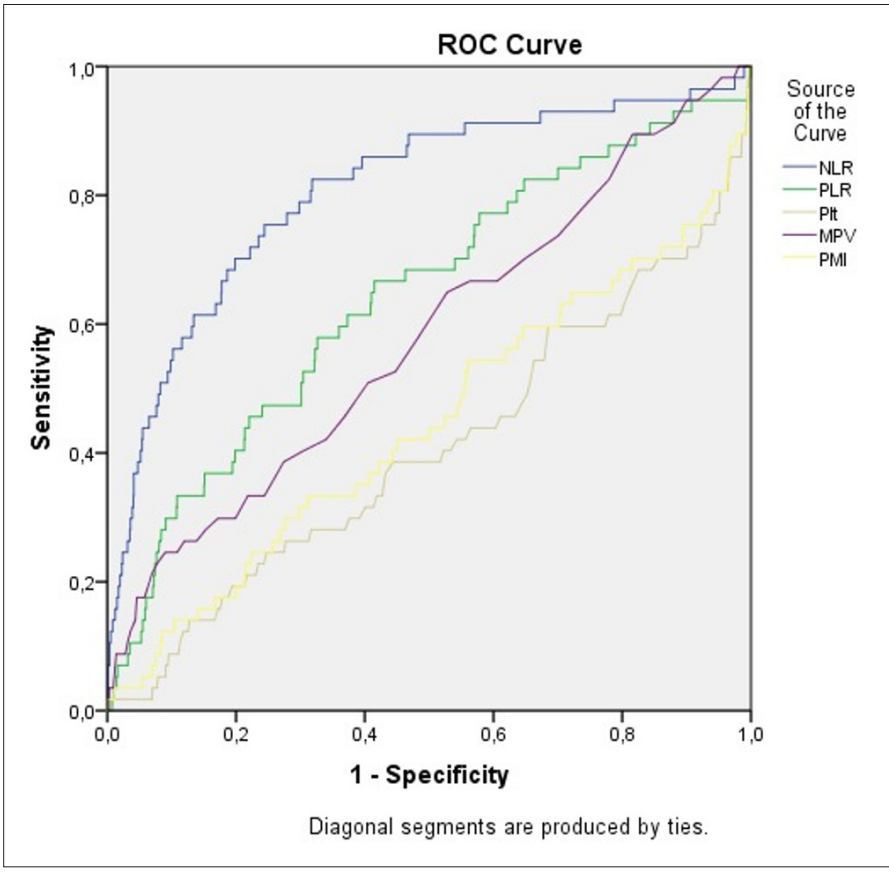

Figure 1. Receiver operating characteristic curves for the mean platelet volume (MPV), neutrophil-to-lymphocyte ratio (NLR) platelet-to-lymphocyte ratio (PLR) platelet mass index (PMI) and platelet count (PIt) for the prediction of 30-day mortality in patients with COVID-19
95\% confidence interval values for the patients.

\section{DISCUSSION}

In this study, we investigated predictability of PMI for 30-day mortality. However, PMI was not useful in predicting 30-day mortality in patients with COVID-19 in ED. To the best of our knowledge, this is the first study that investigates predictability of PMI for 30-day mortality in patients with COVID-19.

In our analysis, parametric comparison tests were used to determine the significant difference between the survivors and the non-survivors in terms of platelet count, MPV and PMI values firstly. No significant relationship was found between them and the mortality. On the other hand, another analysis was performed based on the ROC curve to control the three parameters' ability of 30-day mortality. AUC values $<0.5$ were evaluated as close to random, while those close to one were considered close to the optimum predictor. ${ }^{[7,8]}$ It has been reported that the AUC value should be $>0.8$ for a model to distinguish whether a patient survived or died. ${ }^{[7,8]}$ In the discriminatory power analysis, we found the AUC value of platelet count, MPV and PMI as 0.593, 0.579, and 0.555, respectively which was unacceptable. Thus, according to ROC 
analysis, this retrospective study with over 1500 patients, was verified that platelet count, MPV and PMI were not predictor of 30-day mortality in patients with confirmed COVID-19.

Platelet count has been investigated in infection, sepsis, septic shock and viral pneumonia and has been shown to predict mortality ${ }^{[9]}$ In their study with over 1400 patients, Yang et al. ${ }^{[10]}$ found that thrombocytopenia was associated with inhospital mortality. Liu et al..$^{[11]}$ showed that initial platelet count and changes in platelet count may be associated with mortality in their study in the early period of the pandemic and suggested that platelet count should be followed during hospitalization. Abnormal hematopoiesis due to infection of the bone marrow, immune-thrombocytopenia due to immune complexes and autoimmunity, and consumption thrombocytopenia due to microembolism and thrombosis have been held for thrombocytopenia. ${ }^{[12]}$ However, some studies in the literature have shown that platelet count is not associated with mortality. ${ }^{[13,14]}$ Bozan et al. ${ }^{[13]}$ showed that there was no difference between survivors and non-survivors in terms of platelet count. Güçlü et al. ${ }^{[14]}$ reported that there was no difference in platelet count between moderate and severe COVID-19 patients in their study.

In the current literature MPV has been found to be associated with mortality and poor outcome in malignancy, sepsis, and inflammation-related diseases. ${ }^{[15]}$ Abnormal hematopoiesis due to infection of the bone marrow or immune complexes cause immature synthesis of platelets and abnormal volumes of platelets. ${ }^{[15]}$ Based on this mechanism, the researchers investigated the relationship between MPV and COVID-19. ${ }^{[16-18]}$ Sertbaş et al. ${ }^{[16]}$, in their study with over 9000 patients, reported that MPV is a powerful predictor of mortality in hospitalized patients with COVID-19. Ouyang et al. ${ }^{[17]}$ showed initial MPV and follow-up MPV higher on non-survivor group than survivors. Aktaş et al. ${ }^{[18]}$ found that MPV had no prognostic value in geriatric COVID-19 patients in their study named "Is Mean Platelet Volume Useful for Predicting the Prognosis of COVID-19 Diagnosed Patients?".

There are limited publications in the literature about PMI, which is formed by multiplying platelet count and MPV. ${ }^{[1,20]}$ Girgin et al. ${ }^{[19]}$ reported in their study that low PMI levels are associated with poor prognosis. Okur et al. ${ }^{[20]}$ showed that premature infants with bronchopulmonary dysplasia, necrotizing enterocolitis, retinopathy of prematurity, intraventricular hemorrhage and sepsis had lower PMI levels in early postnatal life than infants without these diseases. [20] They speculated that their results may be caused from inflammatory process. Our study was carried out with a similar hypothesis. Our results showed PMI is not predictor of 30-day mortality in patients with COVID-19. A logical explanation for this might be that platelet count and MPV were not predictors in our cohort.

\section{Limitations}

The main limitation of our study was its retrospective nature. Secondly, we could not include patients with corrected COVID-19 who hadn't been tested for platelet count and MPV. This was the most important limiting factor for our study population. Thirdly we did not exclude the chronic diseases that can affect the platelets as diabetes, renal diseases, and hypoxemia. Another limitation of our study was that the patients discharged from the hospitalized patients during the 30-day follow-up period and the length of hospital stay could not be recorded. Lastly, our study had single-center study, and therefore the results cannot be generalized to other healthcare institutions. We recommend multicenter studies in large populations to increase the generalizability of the results and to confirm them.

\section{CONCLUSION}

According to our results, platelet count, MPV and PMI were not predictor of 30-day mortality in patients with confirmed COVID-19 in ED. We recommend multicenter studies in large populations to increase the generalizability of the results and to confirm them.

\section{ETHICAL DECLARATIONS}

Ethics Commite Approval: The ethical committee approval of our study was obtained from the Ethical Committee of University of Health Sciences, Ümraniye Training and Research Hospital (approval number: B.10. 1.TKH.4.34 .H.GP.0.01/235).

Informed Consent: Because the study was designed retrospectively, no written informed consent form was obtained from patients

Referee Evaluation Process: Externally peer-reviewed.

Conflict of Interest Statement: The authors have no conflicts of interest to declare.

Financial Disclosure: The authors declared that this study has received no financial support.

Author Contributions: All of the authors declare that they have all participated in the design, execution, and analysis of the paper, and that they have approved the final version.

\section{REFERENCES}

1. Özdemir S, Algın A. How will the Health Literacy and Crowded Emergency Room Be Affected After the COVID-19 Pandemic? Phnx Med J 2021;3:50.

2. Zhou B, Kojima S, Kawamoto A, Fukushima M. COVID-19 pathogenesis, prognostic factors, and treatment strategy:Urgent recommendations. J Med Virol. 2021;93(5):2694-704.

3. Gallo Marin B, Aghagoli G, Lavine K, et al. Predictors of COVID-19 severity:A literature review. Rev Med Virol. 2021;31(1):1-10.

4. Ye W, Chen G, Li X, et al. Dynamic changes of D-dimer and neutrophillymphocyte count ratio as prognostic biomarkers in COVID-19. Respiratory Research. 2020;21(1):169.

5. Bairwa M, Kumar R, Beniwal K, Kalita D, Bahurupi Y. Hematological profile and biochemical markers of COVID-19 non-survivors:A retrospective analysis. Clin Epidemiol Glob Health 2021;11:100770.

6. Seyit M, Avci E, Nar R, et al. Neutrophil to lymphocyte ratio, lymphocyte to monocyte ratio and platelet to lymphocyte ratio to predict the severity of COVID-19. Am J Emerg Med 2021;40:110-4.

7. Hanley JA, McNeil BJ. The meaning and use of the area under a receiver operating characteristic (ROC) curve. Radiology 1982;143(1):29-36. 
8. Özdemir S, Akça HŞ, Algın A, Altunok İ, Eroğlu SE. Effectiveness of the rapid emergency medicine score and the rapid acute physiology score in prognosticating mortality in patients presenting to the emergency department with COVID-19 symptoms. Am J Emerg Med 2021;49:259-64.

9. Pulavendran S, Rudd JM, Maram P, et al. Combination Therapy Targeting Platelet Activation and Virus Replication Protects Mice against Lethal Influenza Pneumonia. Am J Respir Cell Mol Biol 2019;61(6):689-701.

10. Yang $X$, Yang $Q$, Wang $Y$, et al. Thrombocytopenia and its association with mortality in patients with COVID-19. J Thromb Haemost. 2020;18(6):146972.

11. Liu Y, Sun W, Guo Y, et al. Association between platelet parameters and mortality in coronavirus disease 2019: Retrospective cohort study. Platelets. 2020;31(4):490-6.

12. Özdemir S, Eroğlu SE, Algın A, et al. Analysis of laboratory parameters in patients with COVID-19: Experiences from a pandemic hospital. Ann Clin Anal Med 2021;Online Preprint. doi:10.4328/ACAM.20678

13. Bozan O, Çekmen B, Atiş ŞE, et al. Prognostic value of neutrophil to lymphocyte ratio and platelet to lymphocyte ratio for mortality in patients infected with SARS-CoV-2. Ukr J Nephrol Dial 2021;2(70):19-31.

14. Güçlü E, Kocayiğit H, Okan HD, et al. Effect of COVID-19 on platelet count and its indices. Rev Assoc Med Bras (1992). 2020;66(8):1122-7.

15. Akoglu EU, Özdemir S, Ak R, Ozturk TC. The Discriminative Power of Inflammatory Markers in Patients with Mild-To-Moderate Acute Pancreatitis:Mean Platelet Volume, Neutrophil-Lymphocyte Ratio, Lymphocyte-Monocyte Ratio, and Neutrophil-Monocyte Product. South Clin Ist Euras. 2021;32(2):159-64

16. Sertbaş M, Dağcı S, Kızılay V, et al. Mean Platelet Volume as an Early Predictor for The Complication of Coronavirus Disease 19. Haydarpasa Numune Med J. 2021;61(2):177-82.

17. Ouyang SM, Zhu HQ, Xie YN, et al. Temporal changes in laboratory markers of survivors and non-survivors of adult inpatients with COVID-19. BMC Infect Dis. 2020;20:952.

18. Aktaş A, Sener K, Yilmaz N, Tunc M, Yolcu S. Is mean platelet volume useful for predicting the prognosis of COVID-19 diagnosed patients? Int J Res Stud Med Health Sci 2020;7:8-11.

19. Girgin R, Cinar O, Bulut E, Akduman B, Mungan NA. The role of the Platelet Mass Index (PMI) as a new prognostic factor in Fournier's gangrene. Afri J Urol. 2018;24(3):226-32.

20. Okur N, Buyuktiryaki M, Uras N, et al. Platelet mass index in very preterm infants:can it be used as a parameter for neonatal morbidities? J Matern Fetal Neonatal Med. 2016;29(19):3218-22. 